\title{
Comparative Analysis of Marketing System Peculiarities for Higher Education in Russian Regions
}

\author{
Arthur A. Maksaev \\ Department of Management and Trade, Krasnodar Cooperative Institute, Russia \\ Received October 12, 2020; Revised December 7, 2020; Accepted December 18, 2020
}

\section{Cite This Paper in the following Citation Styles}

(a): [1] Arthur A. Maksaev, "Comparative Analysis of Marketing System Peculiarities for Higher Education in Russian Regions," Universal Journal of Educational Research, Vol. 8, No. 12B, pp. 8362-8368, 2020. DOI: 10.13189/ujer.2020.082641.

(b): Arthur A. Maksaev (2020). Comparative Analysis of Marketing System Peculiarities for Higher Education in Russian Regions. Universal Journal of Educational Research, 8(12B), 8362-8368. DOI: 10.13189/ujer.2020.082641.

Copyright $\mathrm{C} 2020$ by authors, all rights reserved. Authors agree that this article remains permanently open access under the terms of the Creative Commons Attribution License 4.0 International License

\begin{abstract}
All service sectors need marketing support, though there are specific economic activities which require the development of targeted measures. Among such activities is higher education which specifics lies in the dual nature of its value to society especially for regions significantly distanced from the developed capital. The article discusses the functioning specifics of the higher education system for a group of territories in terms of their attractiveness and competitiveness in the market of educational services. As objects of the study, we selected the regions that vary in the level of demand for educational services and the popular higher education programmes (the Krasnodar region, the Moscow region, Moscow city). The main objective of the study is to identify the peculiarities of marketing policy implementation in the universities from the different territories to draw the attention of service customers. The relevance of the topic is determined by the increasing regional disparities in the market distribution of higher education services against the background of a general decline in the target audience of consumers. We apply content analysis of key queries across the analyzed regions as the main analytical instrument. As a result, this information formed the basis for identifying the directions of the requests and their inclusion in the priority objects of university marketing policies.
\end{abstract}

Keywords Marketing, Higher Education, Provincial Education, Cross-Regional Differences, Regional Education System, Content Analysis, Cross-Regional Comparison, Consumer of Educational Services, Marketing Strategy, Branch Education

\section{Introduction}

Nowadays a topical issue for higher education is its declining popularity for provincial regions, where the marketing policy is not a mandatory part of higher school activities with traditional social institutions having reduced requirements to applicants' education in the labour market. Often, employers in peripheral areas choose mid-level specialists with experience over graduates with a Bachelor's degree.

The main hypothesis of the study lies in the assumption that low interest among consumers of higher education services in the offers from regional organizations presumably serves as an indicator of a weak marketing policy in universities. To date, there is no common theoretical approach conveying the essence of a marketing strategy for organizations implementing higher education programmes. A number of foreign and Russian researchers are involved in developing marketing sphere of higher education. Alina Filip in her research defines the role of educational marketing being in achieving a balance between the agreed individual interests in education and upbringing with the collective needs of society as a whole (Filip, 2012). This a classical position relying on the basic marketing concepts described by Kotler (Kotler, 1984).

Lidia Bialon (2015) believes that «the marketing strategy of the university is a peculiar program of its activity within the educational service market with its content representing directions for strategic and 
operational actions in the market and within the establishment...» (Białoń, 2015).

S. Nedelko and A. Ostashkov (2012) formulate the university marketing task as the necessity to transform the knowledge-oriented (incl. educational) needs of society into profitable opportunities for long-term sustainable development of the university. This approach considers the requirements of the service provider, whereas the public interest is also pointed out by the authors as the demand for knowledge free of the personal background with its value revealing in the future (Nedelko \& Ostashkov, 2012).

Scientific work of S. Fomina (2008) relies on the following basic formulation: the marketing of educational services is a mechanism of interaction between subjects and objects within the education market determining continuous intellectual development of individuals, organizations and society...» (Fomina, 2008).

To summarize, marketing in the higher education system is a necessary market instrument aiming at satisfying all interested user groups. In this case, the service providers are educational institutions (state and commercial) and consumers are applicants, parents (guardians), labour market (Shevchenko, 2016).

The main purpose of the study is to identify differences in the marketing strategy formed for educational institutions in the capital region and regions with a peripheral location. Can I use a single marketing strategy regardless of the geographical location? To achieve this goal, the entire study will have several stages:

1. Analytical review of basic indicators of the regional higher education market system;

2. Content analysis of popular queries in the field of higher education (established phrases, training profile)

3. Comparison of results and formulation of conclusions on the feasibility of using special tools of marketing policy of higher education in the studied territories.

As reference literature, we used scientific research by Russian scientists, which partially reveals the goal outlined in our study (Tarasova E.E., Althonoyan A., Shein E.A., 2017) (Mushketova N., 2015), (Ambarchumjan L.I., Filimonova L.I., Filimonova M.A., Shevchenko E.V., 2020).

\subsection{Factors Influencing University Marketing Strategy}

During their life course, higher education Institutions encounter a number of limiting and promoting factors that vary in nature and impact. Surveying the scientific literature, we identified two sets of factors that include a significant array of second-order factors:

- factors of the external environment. These factors cannot be corrected and remain unchanged for the service provider, so universities must develop an adaptive marketing strategy that incorporates different variations of political, economic, social and environmental conditions of its implementation (Matskevich, 2015). This group of factors can also include the university location, which remains permanent and unchanged at the global level. The list of factors may vary depending on the institution size and profile as well as the demand of the regional market environment, for example, the presence of single-profile educational institutions in a limited area or the agrarian orientation of the regional economy (Olaleke, Banji, Bankole, Maxwell, Omisade, \& Taiye, 2018).

- factors of the internal environment. This group of factors is of market nature. To achieve a high level of commercial efficiency, it is necessary for the university to account and adjust these factors. T.G. Khurumova provides the following rationale for the inner environment of the university: «The internal environment contains data on educational programmes, the quality of faculty, resources and facilities, the level of modern educational technologies, additional services for the learning process, possibilities for continuing and additional education, opportunities to engage in creative or sporting activities» (Hurumova, 2013).

To increase competitiveness and cost-effectiveness educational institutions, thus, it should adapt the marketing strategy to current conditions irrespective of their activities and strengthen internal immunity for the risk-resistance. This is particularly the case for regional provincial universities as they lack an attractiveness of educational institutions of the capital region (Rubaiyet, 2013).

These groups of factors are only a small part of a significant body of theoretical research by Russian authors (Matskevich S. A., 2015), (Butenko E. A. (2013) (Hurumova, 2013). During the review of existing approaches, we identified the following features of the demarcation of factors affecting the marketing strategy of higher education institutions:

- the authors do not distinguish groups of factors for institutions with different territorial locations, assuming that the influence of individual factors is the same for both regional and Metropolitan institutions;

- in most cases, the level of social infrastructure development is considered as an indicator of the development of territories and, as a result, the attractiveness of the territory where the institution is located.

\section{Methodology}

The general purpose of the study is to identify «weaknesses» of provincial higher education institutions in comparison with the ones of the capital region, to 
define "gaps" in marketing activities.

To achieve the purpose, we define a set of tasks:

- $\quad$ analyzing the attractiveness of the higher education in terms of investigated regions;

- revealing the competitive advantages of the internal environment of higher education in the investigated regions;

- identifying the popularity level of higher education institutions;

- reviewing the marketing instruments used by the analyzed universities.

In order to provide a comprehensive solution to the tasks and achieve the overall objective of the thesis, a general and special research methodology was applied in the work. General research techniques include dialectics, induction and deduction, systematic method, and an integrated approach. The special techniques providing the study results include marketing research methods (statistical processing and empirical data analysis, observation, content analysis).

Content analysis was used due to the lack of official statistics on the subject under study. The analysis of queries was carried out based on the data from "Wordstat Yandex" service (Statistics the selection of the words, 2020).

The research team followed the following methodological principles:

1. the principle of a systematic approach to the study of the features of the regional higher education system will allow you to scale the research results to similar types of regional educational systems in the formation of a marketing strategy;

2. the principle of diversity of research forms is represented by a combination of analytical approaches and procedures, as a result of which we will make a comprehensive conclusion on the state of the higher education system;

3. the principle of taking into account regional specifics is based on the results of analytical reviews in the context of regional statistics. This principle is necessary for formulating accurate research results.

\section{Results}

The analytical part of the study includes analysis and identification of regional patterns of higher education in the investigated areas. To draw the correct conclusions, the groups of indicators under consideration were conditionally divided into ones characterizing external and internal development factors of higher education in the region (author's vision). The following analytics was formed according to the data from the Ministry of Education of the Russian Federation for 2019. In order to compare the development level of HE system, we select three territories contrasting in geographical location, administrative status and the level of attractiveness for potential clients (Moscow city, the Moscow region, the Krasnodar region).

Table 1 contains the data on the demand for all organizations implementing higher education programmes. The main advantage of the higher education system in the city of Moscow is its capital location that attracts clients from different regions of the Russian Federation. The concepts of «Moscow universities» and «prestigious education» have long been synonymous in Russia. For this reason, the choice of a place to study is obvious for many students. A large number of organizations create favourable conditions for consumers in choosing a future profession, tuition on a fee-paying and non-fee-paying basis, admission and employment capacity. Among the regions compared, there are 146 independent educational organizations within the territory of Moscow with a total number about 700,000 students in 2019.

The Moscow region is part of Moscow and the Moscow region agglomeration. On the one hand, it has a positive impact as the territory attracts a large number of customers, on the other hand, the region is unable to compete with higher education institutions in the metropolitan area. Branches dominate in the higher education system of the Moscow region attracting nine times more students than the branches in the city of Moscow. The ratio of students graduated to students enrolled was 0.81 in 2019 ( 0.84 in Moscow city). The number of students in the Moscow region amounts to 11.5 per cent of the level in Moscow.

Table 1. Analysis of demand for higher education institutions by region (2019) (external factors)

\begin{tabular}{|l|c|c|c|}
\hline \multirow{2}{*}{ Indicators } & \multicolumn{3}{|c|}{ Investigated region } \\
\cline { 2 - 4 } & $\begin{array}{c}\text { Moscow } \\
\text { city }\end{array}$ & $\begin{array}{c}\text { Moscow } \\
\text { region }\end{array}$ & $\begin{array}{c}\text { Krasnodar } \\
\text { region }\end{array}$ \\
\hline $\begin{array}{l}\text { 1. Number of independent } \\
\text { educational institutions, units }\end{array}$ & 146 & 25 & 19 \\
\hline 2. Number of branches, units & 6 & 37 & 26 \\
\hline 3. Number of students, people & 699843 & 80792 & 109182 \\
\hline $\begin{array}{l}\text { 4. Number of students in } \\
\text { branches, people }\end{array}$ & 3319 & 21621 & 23687 \\
\hline $\begin{array}{l}\text { 5. Number of students } \\
\text { enrolled, people }\end{array}$ & 215030 & 20164 & 27597 \\
\hline $\begin{array}{l}\text { 6 Number of students } \\
\text { graduated, people }\end{array}$ & 182551 & 16454 & 26367 \\
\hline $\begin{array}{l}\text { 7. Percentage of students with } \\
\text { education funded from } \\
\text { budget resources with full } \\
\text { cost recovery, \% }\end{array}$ & 58.2 & 57.3 & 66.6 \\
\hline
\end{tabular}

Source: (Open statistics of the Ministry of Education of the Russian Federation, 2020)

The Krasnodar region is a peripheral region comparing to Moscow and the Moscow region. It is part of the Southern Federal District with a high density of settlements and an economically active population. The higher education system in the region is represented by 19 independent organizations and 26 branches. The number 
of students was 109,182 in 2019 , which is $35 \%$ higher than the level of the Moscow region. There is a demand for higher education due to the large local population and the good location of the regional centre (Krasnodar) attracting students from neighbouring regions (the Stavropol region, the Rostov region) and relatively low competitiveness of higher education in the border regions. In 2019 , the ratio of graduated students was $95 \%$ of the enrolled students' numbers, which is the best result among the investigated regions.

Indicated advantages constitute a base of external factors having a direct impact on the attractiveness and reputation of higher education. In Table 2.3 below, there is a sampling on the internal environment factors of higher education institutions from a regional perspective, which are subject to continuous monitoring and regulation by increasing or reducing their competitive advantage.

Table 2. Number of faculty members by region (internal factors)

\begin{tabular}{|c|c|c|c|}
\hline \multirow{2}{*}{ Indicators } & \multicolumn{3}{|c|}{ Investigated region } \\
\cline { 2 - 4 } & $\begin{array}{c}\text { Moscow } \\
\text { city }\end{array}$ & $\begin{array}{c}\text { Moscow } \\
\text { region }\end{array}$ & $\begin{array}{c}\text { Krasnodar } \\
\text { region }\end{array}$ \\
\hline $\begin{array}{c}\text { 1.Facultyoverall } \\
\text { (people) }\end{array}$ & 47528 & 3862 & 4957 \\
\hline$\bullet \quad \begin{array}{l}\text { of them, } \\
\text { doctors of } \\
\text { sciences }\end{array}$ & 8884 & 549 & 832 \\
\hline$\bullet \quad \begin{array}{c}\text { candidate of } \\
\text { sciences }\end{array}$ & 25095 & 2416 & 3068 \\
\hline
\end{tabular}

Source: (Open statistics of the Ministry of Education of the Russian Federation, 2020)

The faculty staff of the university is the most important indicator of the education quality, which characterizes the capability of the system to effectively relay knowledge increasing the human capital capacity of the next generation. The cross-regional comparison is not entirely correct as the staff numbers depend on the number of educational institutions. Moscow is an educational centre of Russia that attracts high-level professionals creating personnel transfer from regional educational institutions to the capital ones. The level of doctorates per a separate organization is the highest in Moscow with 60 people, then in the Krasnodar region with 43 people and the Moscow region with 20 people. The corresponding hierarchy is also observed for candidates of sciences. The rate of academic degree holders among the staff is one of the main rating indicators for higher education institutions. Many universities use it for marketing purposes in their public promotional events.

To attract the clients, universities use their scholarship funds volumes as a strong argument possibly serving as a financial guarantor for many future students with financial problems and being particularly relevant for students from rural areas. According to information from the Ministry of Education of the Russian Federation, various scholarship programmes are actively implemented in sufficient quantity in the regions investigated. In the Krasnodar region, every fifth student is a scholarship recipient, whereas it is every third student in Moscow.

Table 3. Scholarship opportunities of universities by region (internal factors)

\begin{tabular}{|c|c|c|c|}
\hline \multirow[b]{2}{*}{ Indicators } & \multicolumn{3}{|c|}{ Investigated region } \\
\hline & $\begin{array}{l}\text { Moscow } \\
\text { city }\end{array}$ & $\begin{array}{l}\text { Moscow } \\
\text { region }\end{array}$ & $\begin{array}{c}\text { Krasnodar } \\
\text { region }\end{array}$ \\
\hline $\begin{array}{l}\text { Number of full-time students } \\
\text { receiving: } \\
\text { - } \quad \text { State academic } \\
\text { scholarships }\end{array}$ & 186113 & 14980 & 19403 \\
\hline $\begin{array}{ll} & \text { State social } \\
\text { scholarships }\end{array}$ & 23407 & 3081 & 3473 \\
\hline $\begin{array}{l}\text { - } \\
\text { Pcholarships of the } \\
\text { Russian Federation }\end{array}$ & 436 & 4 & 37 \\
\hline 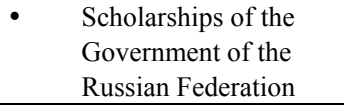 & 703 & 15 & 61 \\
\hline - $\quad$ Name scholarships & 4803 & 588 & 199 \\
\hline $\begin{array}{l}\text { - } \quad \begin{array}{l}\text { Scholarships assigned } \\
\text { by legal entities }\end{array} \\
\end{array}$ & 2422 & 413 & 14 \\
\hline $\begin{array}{l}\text { - } \quad \begin{array}{l}\text { Scholarships assigned } \\
\text { by natural persons }\end{array} \\
\end{array}$ & 6 & - & - \\
\hline
\end{tabular}

Source: (Open statistics of the Ministry of Education of the Russian Federation, 2020)

Higher education is a cost-intensive service for non-resident students. Their caregivers bear substantial financial costs for the student's accommodation and the educational process even with budget-based studying. For clients with a low material base, the availability of student dormitories, scholarship funds and free study materials are decisive factors in selecting the university.

When forming local elements of the marketing strategy for higher education institutions, the following information is particularly important:

- Rating of the institution on a national and a regional scale;

- academic degree holders rate among the faculty «staff»;

- focus on regional clients (aiming at the nearest regions);

- the rationale of the university material advantages;

- $\quad$ use of target queries (for network promotion).

\subsection{Content Analysis of Popularity of Regional Higher Education System}

For promotion campaigns, universities can rely on actual queries made by users of interactive resources to obtain information about higher education in the region or about a specific organization. We applied content analysis to the search engine platform "Wordstat Yandex» as a specific sociometric instrument. When forming a query, the service displays the most similar semantical combinations of words. The duration of the study is limited to 18 months that excludes constructing long-term predictive scenarios. 


\section{Statistics of queries on keywords}

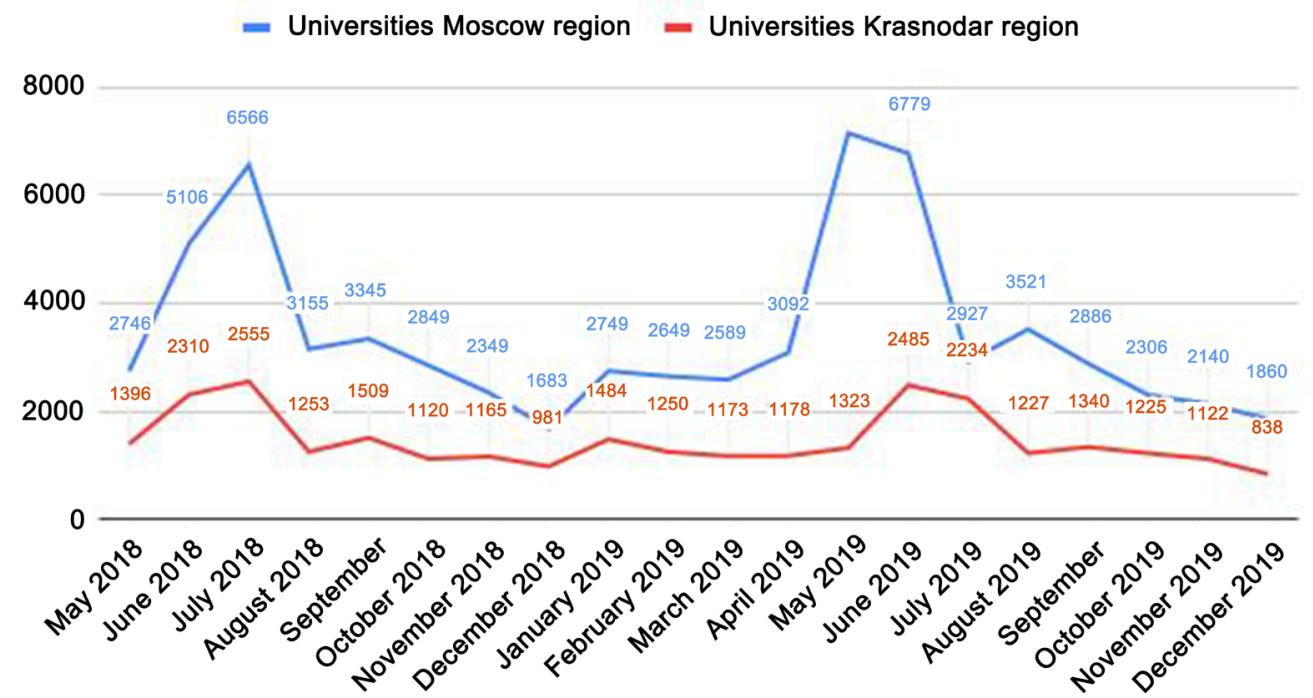

Source: (Open statistics of the Ministry of Education of the Russian Federation, 2020

Figure 1. Statistics of actual queries on keywords "Krasnodar region universities" and "Moscow region universities"

\section{Statistics of queries "Moscow universties"}

400000

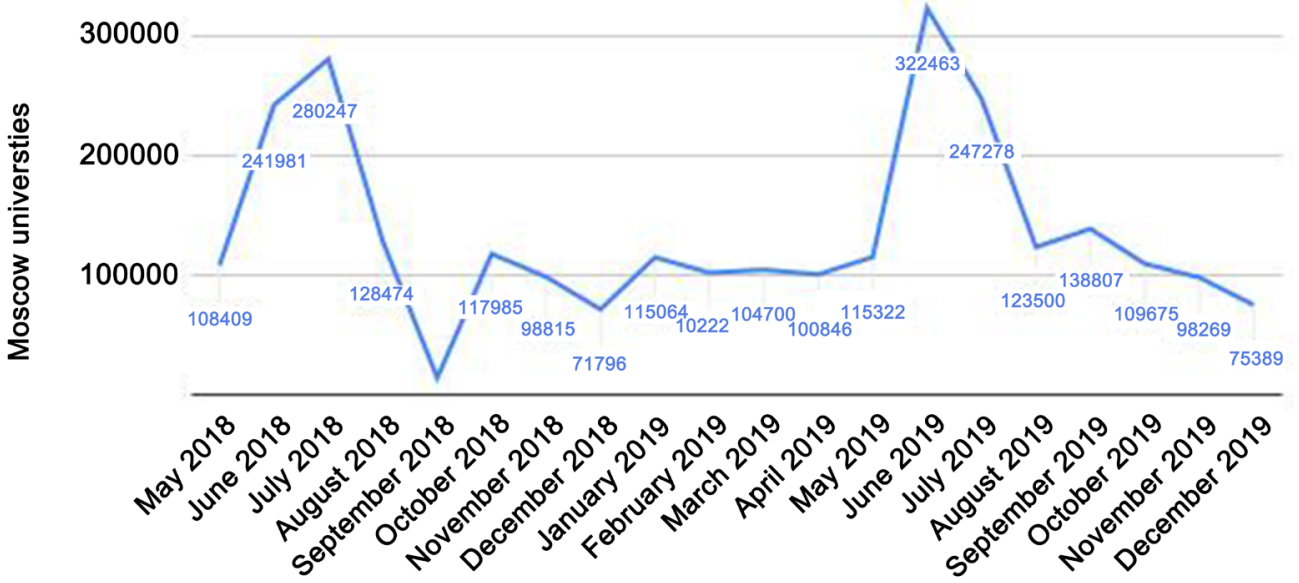

Source: (Open statistics of the Ministry of Education of the Russian Federation, 2020)

Figure 2. Statistics of actual queries on keywords «Moscow universities»

According to the data received the biggest interest of the internet users registered during the period from May to August, which is easily explained due to the end of the school year. It is at this time every year that the problem to choose the form of subsequent education for the future student becomes topical. According to the number of requests, the Moscow region has three times the number of Krasnodar region. The curve on the Krasnodar region has a smaller level of fluctuations during the analyzed period with about 2,000 queries monthly indicating the virtual passivity of the provincial residents in searching for information. Perhaps, a face-to-face promotion of the proposed programmes would be most effective for the regional education. The lowest search activity is observed during the winter months. So significant investment in advertising campaigns will be probably inefficient.

There is a similar trend in Moscow with the peak activity from May to August with a gradual decline towards the end of the calendar year. The absolute minimum is observed in September 2018, which is an anomalous phenomenon and can be associated with a number of external factors independent of the education sector. Comparing the data for two years, it is worth noting the overall increase in requests in 2019 in contrast with 2018 data, which is a positive sign for higher education in the region. 
Table 4. Results of content analysis

\begin{tabular}{|c|c|c|c|}
\hline Name of region & Regions of queries origin & Cities of queries origin & Popular search phrases \\
\hline $\begin{array}{l}\text { Krasnodar } \\
\text { region }\end{array}$ & $\begin{array}{c}\text { Krasnodar region }-603 \\
\text { Moscow and Moscow region }-64 \\
\text { Republic of Crimea }-34 \\
\text { Stavropol region }-28 \\
\text { Rostov region-26 }\end{array}$ & $\begin{array}{l}\text { Krasnodar }-229 \\
\quad \text { Sochi }-71 \\
\text { Moscow }-49 \\
\text { St. Petersburg }-25 \\
\quad \text { Armavir }-20 \\
\text { Rostov-on-Don }-19 \\
\text { Novorossiysk }-16\end{array}$ & $\begin{array}{l}\text { - } \quad \text { Kuban State University } \\
\text { - } \quad \text { Kuban State Agrarian University } \\
\text { - } \quad \text { Universities of Krasnodar region with } \\
\text { budget-funded places } \\
\text { - Technical universities of Krasnodar region }\end{array}$ \\
\hline Moscow region & $\begin{array}{c}\text { Moscow and Moscow region - } \\
1366 \\
\text { Samara region }-23 \\
\text { Stavropol region }-16 \\
\text { Vladimir region-15 }\end{array}$ & $\begin{array}{c}\text { Moscow }-495 \\
\text { Balashikha }-62 \\
\text { Mytishchi }-42 \\
\text { Korolyov }-39 \\
\text { Chekhov }-30 \\
\text { Ivanteevka }-30 \\
\text { Lobnya }-21\end{array}$ & $\begin{array}{ll}\text { - } & \text { Pedagogical university } \\
\text { - } & \text { State humanitarian university } \\
\text { - } & \text { Universities of Moscow and Moscow } \\
\text { - } & \text { region } \\
\text { - } & \text { Unedical universities of Moscow region } \\
\text { - } & \text { State universities of Moscow regionwith } \\
\text { budget-funded places }\end{array}$ \\
\hline Moscow city & $\begin{array}{c}\text { Moscow and Moscow region } \\
-44183 \\
\text { St. Petersburg and Leningrad } \\
\text { region }-2196 \\
\text { Nizhniy Novgorod region }-1875 \\
\text { Krasnodar region }-1679 \\
\text { Samara region }-1504 \\
\text { Sverdlovsk region }-1388 \\
\text { Rostov region }-1081\end{array}$ & $\begin{array}{c}\text { Moscow -29976 } \\
\text { St. Petersburg }-1919 \\
\text { Nizhniy Novgorod }-1392 \\
\text { Samara -1148 } \\
\text { Balashikha }-1067 \\
\text { Yekaterinburg }-899 \\
\text { Krasnodar }-857 \\
\text { Novosibirsk -785 } \\
\text { Podolsk -725 } \\
\text { Khimki -708 } \\
\text { Ufa -642 } \\
\text { Rostov-on-Don }-635\end{array}$ & $\begin{array}{ll}\text { - } & \text { Moscow higher educational institution } \\
\text { - } & \text { University of Moscow } \\
\text { - } & \text { Moscow university } \\
\text { - } & \text { Budgetary universities of Moscow } \\
\text { - } & \text { Education universities of Moscow } \\
\text { - } & \text { Higher education universities of Moscow } \\
\text { - } & \text { Rating of Moscow universities } \\
\text { - } & \text { Best universities of Moscow }\end{array}$ \\
\hline Moscow city & $\begin{array}{c}\text { Moscow and Moscow region } \\
-44183 \\
\text { St. Petersburg and Leningrad } \\
\text { region }-2196 \\
\text { Nizhniy Novgorod region }-1875 \\
\text { Krasnodar region }-1679 \\
\text { Samara region }-1504 \\
\text { Sverdlovsk region }-1388 \\
\text { Rostov region }-1081\end{array}$ & $\begin{array}{c}\text { Moscow -29976 } \\
\text { St. Petersburg -1919 } \\
\text { Nizhniy Novgorod }-1392 \\
\text { Samara }-1148 \\
\text { Balashikha }-1067 \\
\text { Yekaterinburg }-899 \\
\text { Krasnodar }-857 \\
\text { Novosibirsk -785 } \\
\text { Podolsk -725 } \\
\text { Khimki -708 } \\
\text { Ufa -642 } \\
\text { Rostov-on-Don }-635\end{array}$ & $\begin{array}{ll}\text { - } & \text { Moscow higher educational institution } \\
\text { - } & \text { University of Moscow } \\
\text { - } & \text { Moscow university } \\
\text { - } & \text { Budgetary universities of Moscow } \\
\text { - } & \text { Education universities of Moscow } \\
\text { - } & \text { Higher education universities of Moscow } \\
\text { - } & \text { Rating of Moscow universities } \\
\text { - } & \text { Best universities of Moscow }\end{array}$ \\
\hline
\end{tabular}

Source: Statistics the selection of the words, 2020

Furthermore, after analyzing the content analysis data, we created table 4 with the information on query locations and popular query topics.

The geography of queries from the Krasnodar region is limited to intraregional locations. As for cities of origin, 82 per cent of the queries come from cities in the region. In the Moscow region, the main users are from Moscow and the cities in the region (96\%). Higher education in the city of Moscow attracts the interest of users across a wide geographical range, although a vast majority of queries come from Moscow and the Moscow region.

The highlighted phrases are actively used by internet users to search for information about higher education in the region of their interest or about a specific educational institution, which can also be used by universities to generate hash tags for online advertising campaigns.

\section{Conclusions}

The study we identified disparities in interregional development level of the higher education system, as in the value of attracted contingent, and the number of teaching staff and level of training. We also drew attention to the regional specifics of the level of development of the branch network, which is a feature near the capital territory and is not developed in the peripheral zone. Thus, the identified differences indicate the need for an adaptive marketing strategy system.

As a result, we have drawn general conclusions on the functioning specifics of higher education institutions in each region and in accordance with the content analysis formulated recommendations for implementing the marketing strategy:

1. Moscow city. The higher education system there has no shortage of demand. Internet users from many Russian regions both adjacent to the city and located thousands of kilometres away are actively interested in this sphere. The search engine registers a high intensity of queries with keywords directly or indirectly related to the capital higher education 
system. The geographical location of the organization within the city area (Moscow) plays a crucial role with all other things being equal in competing with the regional provincial universities. For Moscow institutions, it is practicable to place maximum focus on advertising campaigns in the following regions: the Leningrad region, the Nizhny Novgorod region, the Krasnodar region. Factors of the external environment play a crucial role in the high competitiveness of the industry.

2. Moscow region. The regional higher education is in the shadow of the capital one and unable to provide more attractive conditions being in the immediate vicinity of the leading territory of Russian education. However, this region occupies its niche, which is a branch education, attracting students from nearby settlements as confirmed by the content analysis. Thus, the marketing policy of the regional organizations should aim at retaining the potential range of services users by applying as many instruments as possible (from webinars to face-to-face events with personal offers). Internal factors come to the fore for the region as only reputational advantages can attract more clients.

3. Krasnodar region. The main advantage of the regional higher education system is its location in the area with a significant level of social and economic development, favourable natural and climatic living conditions and quality of life. Factors of external environment determined the popularity of higher education in the region. The content-analysis revealed the weak user activity in searching for information about education in the Krasnodar region. It is practicable to use marketing instruments directly within the territory and beyond.

\section{REFERENCES}

[1] Ambarchumjan L.I., Filimonova L.I., Filimonova M.A., Shevchenko E.V. (2020) Features of promoting educational services in modern conditions. Economics of sustainable development .2 (42).2-5.

[2] Białoń, L. (2015). Creating marketing strategies for higher education institutions. MINIB , 4 (18), 129-146.

[3] Butenko E. A. (2013). Marketing support of educational activities as a strategy for the development of Russian universities in the near and medium term. Economics and entrepreneurship. 8. 21-32.

[4] Filip, A. (2012). Marketing theory applicability in higher education. Procedia-Social and Behavioral sciences (46), 912-916.

[5] Fomina, S. (2008). Marketing of educational services at training of high-demand specialists in Russian regions. Volgograd: Volgograd.

[6] Hurumova, T. (2013). Features of marketing in higher education. Terra economics , 11/3, 165-170.

[7] Kotler, P. (1984). Marketing Essentials. Englewood Cliffs,N.J.: Prentice-Hall.

[8] Matskevich, S. (2015). External factors that determine the marketing strategy of higher education institutions. Economics and management of innovative technologies , 12, 5-16.

[9] Mushketova N. (2015) Strategic marketing adaptation of the Russian universities in a dynamic environment. National interests priorities and security.27.12-22.

[10] Nedelko, S., \& Ostashkov, A. (2012). University marketing as a tool for its sustainable development. The power (12), $88-92$.

[11] Olaleke, O., Banji, A., Bankole, O., Maxwell, O., Omisade, A., \& Taiye, B. (2018). Data set on interactive service quality in higher education marketing. Data in Brief, 1403-1409.

[12] Open statistics of the Ministry of Education of the Russian Federation. (2020, 01 15). Retrieved 01 20, 2020, from minobrnauki.gov.ru: http://www.minobrnauki.gov.ru

[13] Rubaiyet, H. K. (2013). Marketing education online:a case stude of New Zaland higher education institutions. Procedia-social and behavioral sciences , 637-646.

[14] Shevchenko, D. (2016). Marketing education: basic comprehension of approaches and tools to understand the education market. Psychology and pedagogics in official activities (3), 16-22.

[15] Statistics the selection of the words. (2020, 05 13). Retrieved 05 14, 2020, from wordstat.yandex.ru: http://www.wordstat .yandex.ru

[16] Tarasova E.E., Althonoyan A., Shein E.A. (2017) Higher schools' marketing strategy: domestic and foreign experience. Vestnik BUKEP. 2 (63).9-28. 